\title{
An Inquiry into the Legal Considerations for Passenger Mental Injuries in International Aviation Laws
}

\author{
Cheung Chai Hong \\ School of International Law, China University of Political Science and Law, Beijing, China
}

\section{Email address:}

lseandycheung@gmail.com

\section{To cite this article:}

Cheung Chai Hong. An Inquiry into the Legal Considerations for Passenger Mental Injuries in International Aviation Laws. International Journal of Education, Culture and Society. Vol. 3, No. 1, 2018, pp. 19-23. doi: 10.11648/j.ijecs.20180301.15

Received: February 22, 2018; Accepted: April 2, 2018; Published: April 24, 2018

\begin{abstract}
The main purpose of the paper is to discuss law application concerning mental damage compensation to air passengers, and to offer solutions. Though Legal Positivism, the paper analyzes the legislative background and purpose of damage compensation to air passengers in Warsaw System; through comparisons, it discusses the legislative and judicial theories and practices concerning mental damage compensation in China and the US. The study finds that, regulations in the Warsaw System concerning mental damage compensation to air passengers have blurred boundaries, leading to difficulties in application. Though as major aviation powers, China and the US also have strong disagreements on this issue in their relevant laws and judicial precedents at home, also leading to difficulties in application. This paper suggests timely amendments to the Warsaw System, so as to avoid forum shopping, which may disturb law application and tarnish the authority of the System.
\end{abstract}

Keywords: Air Passenger Service, Warsaw System, Mental Injury, Judicial Practice

\section{Introduction}

This paper mainly discusses the legal considerations regarding passenger mental injuries in international aviation laws on the basis of provisions of international conventions the Warsaw Convention system which regulates the responsibilities of international passenger airlines. By reflecting upon the legal regulations and judicial practices in the U.S. - the most developed nation in world's air transportation sector; and in P. R. C. - the quickly rising air transportation powerhouse, this essay attempts to elicit a conclusive ground of understanding over this issue.

\section{Statement of Issue}

\subsection{Considerations for Mental Injury to Air Passengers}

The development of medical jurisprudence benefits significantly from the study of Freud, who first analyzed mental injuries and ascribed these to fear and anxiety. These can lead to adverse changes to human bodies, such as "unpleasant subjective feelings of horror, pounding heart, muscular tension, severe shock etc." [1] In respect of the sources of mental sufferings, three possible types of mental injuries can arise during the course of international passenger service: (1) pure mental injury /mental injury unaccompanied by physical injury, such as fear instilled in passengers due to drastic jolts of the aircraft caused by unstable currents during the flight, for example as a result of severe turbulence caused by airflow instability encountered by the aircraft during the flight which leads to mental fear of passengers; (2) mental injury caused by physical injury to passengers due to aviation incidents, such as mental stress resulting from scalding on body from hot water due to the lack of care from the flight attendants; and (3) physical injury caused by mental injury to passengers in an aviation accident. The latter two can be collectively referred to as "mental injury accompanied by physical injury". [2]

\subsection{Legal Basis for Compensation for Mental Injuries of Passengers}

Mental injuries refers to "a civil law instrument that can be resorted to as means of relief and protection when a civil subject suffers from unlawful harm to his personal rights which constitutes intangible damage to his personality and identity interests or mental suffering, by demanding monetary or in-kind compensation from the tortfeasor." [3] According to the traditional theory of contract law, compensation for mental 
injuries is beyond the scope of compensation for breach of contract. Compensation for mental injuries has to be settled by tort law. Based on the principle of foreseeability in compensation for breach of contract, mental injuries are unforeseeable to the victim at the time of signing contract, and therefore does not fall into the scope of compensation for breach damages. [4] Yet, currently most of the countries and regions worldwide have recognized mental injuries as part of breach liability. For example, in Article 353 of Restatement (Second) of Contracts (Loss Due to Mental injuries), it is provided that, compensation for mental injuries will be excluded unless the breach of contract also causes harm to body, or the contract or the breach of contract is so exceptional that compensation for severe mental injuries is a particularly likely result. It is interpreted as, The contract or the breach of contract that renders mental injuries a particularly likely result, the usual examples may be contracts for transporting passengers, contracts for hotels to accommodate guests, contracts for transporting dead bodies and contracts for delivering grievous messages. Breaching such contracts is particularly likely to cause mental injuries. Under circumstances of any other type of contract is breached, for instance the breach results in destitution or sudden bankruptcy of the victim, or happens to coincidently cause more severe mental injuries. However, as long as such contracts do not provide for mental injuries to be a type of particularly likely risk, claims of mental injury shall not be supported. [5]

\section{Interpretation of the Warsaw System}

The Convention for the Unification of Certain Rules for International Carriage by Air (hereinafter referred to as the "Warsaw Convention") was first formulated and passed in 1929. Over a series of revisions, the Warsaw System was formed and it is currently the primary legal framework for regulating responsibilities of international air transport carrier today. In a general sense, the Warsaw System includes Warsaw Convention (1929), Hague Protocol (1955), Guadalajara Convention (1961), Guatemala Protocol (1971), four Montreal Protocols (1975), Montreal Convention (1999) as an outcome of the modernization reforms of the Warsaw System (effective since November 4, 2003), Montreal Agreement (Provisional) (1966) and IATA Inter-carrier Agreement on Passenger Liability (short for "Kuala Lumpur Agreement", 1995). [6]

\subsection{Relevant Provisions in the Warsaw Convention}

Article 17 of the Warsaw Convention is the key term specifying airline liability for damages, which states, the carrier shall be liable for damages sustained in the event of the death or wounding of a passenger, or any other bodily injury suffered by a passenger that result in losses, if the accident which caused the damage to sustain took place on board the aircraft or in the course of any operations of embarking or disembarking. The French version reads, Le transporteur est responsable du dommage survenu en cas de mort, de blessure ou de toute autre lesion corporelle subie par un voyageur lorsque I'accident qui a cause le dommage s'est produit a bord de I'acronef ou au cours de toutes operations d'embarquement et de debarquement. [7] About "any other bodily injury" to a passenger, the French expression in the Warsaw Convention is "lesion corporelle", and the English translation is "bodily injury". Has compensation for passenger mental injury been included in the above expressions? According to investigations done by scholars, the minutes of the Warsaw Conference indicates, no discussion on this wording has been conducted at the time. Professor Dr. Thomas Risse, a German representative attended the Warsaw Conference and a renowned aviation law specialist, translated the wording into a German expression with a meaning of "any harm to health", which has been adopted by countries including Germany, Austria and Switzerland. Compared to "bodily injury", the translation provided by Dr. Risse can be more likely interpreted as including mental trauma. [8]

However, considering the French version being the authentic text of the Convention and the background of drafting at the time, the drafters seemed to be more inclined to not support claims for pure mental injury. Although no evidence explains the reason for adopting such a specific wording, it does limit the types of injury for which claims can be pursued. [9] It should also be noted that, at the time between 1920s and 1930s when the Warsaw Convention was formulated and passed, theories on human mental injuries and their respective compensation had not gained wide acceptance by worldwide judicial systems, nor in international practices. Although the Convention inclines to not hold air transportation carrier liable for compensation for pure mental injuries to passengers, if mental injuries precedes, accompanies or ensues from bodily injuries, is this possible to make damages claims to carriers?

\subsection{Relevant Provisions in the Hague Protocol and Guatemala Protocol}

As an amendment to the Warsaw Convention on carrier liability, the Hague Protocol and Guatemala Protocol replaced bodily injury by personal injury. As some scholars noted, "personal injury" is obviously a more general term than "bodily injury" and it has covered the meaning of mental injury. [10] However, in a more main-stream point of view, the choice of wordings in the two protocols is unacceptable, as personal injury might be referring to non-material personal harms, such as libel, insult, discrimination, fear and apprehension, which are obviously inadvisable and unacceptable terms for a claim. "Bodily injury" is more likely to be accepted, but this would rule out such mental injuries such as shock." [11]

\subsection{The Standing of the Montreal Convention}

In the draft of the Montreal Convention formulated by the Legal Committee of International Civil Aviation Organization (ICAO) in 1997, it is provided that, "the carrier shall be liable for damages sustained in case of the death, bodily or mental injuries of a passenger upon condition that the death or injuries are caused by accidents take place on board the aircraft or in 
the course of any of the operations of embarking or disembarking; however, if such death or injury of the passenger is entirely caused by the passenger's own health condition, the carrier shall not be liable." [12]

Developed nations led by the U.S. considered that the severity of the consequences from mental injury might be comparable to that from bodily injury. If two passengers both became disabled from aviation accident, one passenger was disabled only due to mental injury while another was physically disabled due to bodily injury, the former would be entitled to much less damages than the latter, which was obviously unfair. The new Convention is not supposed to take discriminative standing on this issue. Considering juveniles are much less equipped to endure mental sufferings than adults not affording mental damages is particularly unfair for juveniles. Many developing nations believed that increasing mental damages was against the fundamental principle of balancing the interests between passengers and carriers in this Convention. Meanwhile, it was very difficult to ascertain the scope of mental injury, and all the nations differed greatly in how to recognize mental injury and how to calculate the damages, which gave rise to uncertainties on the application of the Convention and it was against the spirit of unification and codification that the new Convention was committed to. Two views were diametrically opposed to each other, over which Clause 1 of Article 17 "Death and injury of passengers damage to baggage" in the Montreal Convention was finally passed in 1999, specifying, "the carrier is liable for damage sustained in case of death or bodily injury of a passenger upon condition only that the accident which caused the death or injury took place on board the aircraft or in the course of any of the operations of embarking or disembarking". [13] It can be viewed as, except for excluding death or injury to a passenger entirely caused by his own health condition, there were no other significant adjustments to the effective terms.

\subsection{Summary}

The author regards the Warsaw System as being ambiguous with its standing over air passenger damages claim for mental injury. According to the principles of general treaty laws, in regulating the legal relationships in international air transportation undertaking, the Warsaw System needs to draw support from legal practices of the judicial institutions of its signatory countries. Since the Convention is ambiguous with its statement on this issue, courts in different signatory countries are thereby availed the leeway to interpret the Convention, and in some sense the discretion to exercise their disparate wills in applying the Convention.

\section{Legal Practices in Major Signatory Countries}

\subsection{Analysis of Judicial Precedents in the U.S.}

So far, most states in the U.S. have not yet recognized mental injury as an independent type of liability, and have not fully accepted pure mental injury as a ground of claim. [14] In the case Burnett v. Trans World Airlines Inc., the appellate court regarded the French version of the Warsaw Convention as the authentic text, so it held that the meaning of the French wording in the Convention shall prevail. [15] As in French, mental injury and bodily injury are distinct terms, it means the Convention is not in support of any claim of damages on the ground of pure mental injury, and only mental injury caused by bodily injury shall be awarded damages. In the case Floyd v. Eastern Airlines, the Supreme Court of the United States held that, "if it is for damage from purely mental or psychological injury, according to the Warsaw Convention, this does not fall into the scope of claimable damages, because such injury is beyond the scope of "bodily injury" as specified in Article 17 of the Convention." [16] The U.S. courts hold that mere physiological representation of mental injury does not constitute bodily injury, therefore cannot be awarded damages. Only actual impairment of physical function caused by mental injury can be awarded damages. According to the main-stream view of the U.S. courts, only mental injury caused by bodily injury can be awarded damages; mere physiological representation of mental injury does not constitute bodily injury pursuant to the Convention, therefore cannot be awarded damages; claim on the ground of pure mental injury shall not be supported.

\subsection{Analysis of Relevant Judicial Cases in P. R. C.}

Article 110 [17] of the General Provisions of the Civil Law of the People's Republic of China has stipulated the basis for mental injury and the system of its damages, nonetheless it does not provide a concrete definition for mental injury. In Answers to Several Issues Pertaining to Trial of Reputation Right Related Cases by the Supreme People's Court released in 1993, the concept of mental injury damages was specified for the first time in Clause 4 of Article 10. Mental injury is considered as a non-property damage, and thereby it substantiated the mental damages system in terms of legal applicability. [18] The Interpretation of the Supreme People's Court on Problems regarding the Ascertainment of Compensation Liability for Emotional Damages in Civil Torts (hereinafter referred to as Interpretations on Emotional Damages in Civil Torts) enforced from March 10, 2001 and the Interpretation of the Supreme People's Court of Some Issues concerning the Application of Law for the Trial of Cases on Compensation for Personal Injury (hereinafter referred to as Interpretations on Compensation for Personal Injury) enforced from May 1, 2004 also adopted this wording.

Although the Interpretations on Emotional Damages in Civil Torts allows a litigant to claim damages on mental injury purely on ground of personality rights tort, it also requires that mental injury must be the cause of severe consequences, which means it must be the cause of impairment to physical function. Any request on claim for damages on the ground of pure mental injury can hardly be supported by a court because it would be very difficult for a litigant to provide evidence to prove such mental injury does cause severe consequences. Article 1 [19] of the 
Interpretations on Compensation for Personal Injury affirms that claims for damages of mental injury caused by bodily injury can be supported by courts. Article 18 [20] designates the matter of ascertaining mental injury to be settled by the Interpretations on Emotional Damages in Civil Torts. Domestic laws and regulations in P. R. C. regarding injury damages for air passengers since 1949 have never addressed the issue of damages for mental injury. Therefore, while P. R. C.'s legal system acknowledges the right to damages for mental injury, the mental injury must be either the consequence of bodily injury or the cause of impairment to physical function. Damages claims purely on mental injury can hardly be supported in the current legal practice.

In relevant judicial cases, for example, the International Air Passenger Tort Damages Claim Case between Lu Hong and United Airlines in 2001, [21] the appellate court regarded both the P. R. C. and the U.S. as member countries of the Warsaw Convention and Hague Protocol. As a signatory country, the P. R. C. has the obligation to comply with and obey the Convention. Therefore the Warsaw Convention and Hague Protocol should be first applied to the case. Liabilities of damages for tort were ascertained based on the consequences of the tort, covering not only damages for property losses, and also damages for bodily and mental injuries as well. Since the actions of United Airlines caused certain bodily and mental sufferings to $\mathrm{Lu}$ Hong, her pursue on solatium for mental injury should be duly granted. However, the court did not enunciate the legal basis of granting mental damages to the plaintiff, nor explain the provisions and rules of application of the Warsaw Convention and; rather it directly made the verdict according to the provisions of P. R. C. law. In the case of Yang Ping v. Northwest Airlines in 2005, [22] the appellate court first recognized the Warsaw Convention as the governing law for the case; where the liabilities of the carrier are concerned, it does not only focus on the harm itself, but also the losses thereby incurred to the passenger. The losses generally include material and mental losses; while the passenger sustains injury or other bodily harm, it is accompanied with anxiety, tension, fear and sufferings. Therefore awarding damages accordingly should be considered as what the Warsaw Convention has been designed for and destined. Also, it is a fair and reasonable course of action. The court thereby ruled the Northwest Airlines to pay USD 1 to Yang Ping as mental solatium. The responses of the P. R. C. courts to mental damages claims of air passengers are still grinding over the issue of whether such claims for mental damages caused by bodily injuries should be supported. There have been relatively few judicial practices related to tort damages claims over bodily injury arise from mental injury or damages of pure mental injury. The former type can be supported if a claimant can provide adequate evidence, but the latter type is basically denied.

\section{Conclusion}

Over the issue of ascertaining air passenger mental injury damages, so far the main-stream view is to treat mental injury separately. For mental injury caused by bodily injury, the mental damages can be awarded along with the damages for associated bodily injury. For mental injury causing bodily injury, if such bodily injury is substantiated as impairment of body part or organ function and is not a mere physiological representation of mental injury, the respective damages for bodily and mental injuries can also be awarded. However, pure mental injury suffered by air passenger can hardly be awarded damages.

In the U.S. Supreme Court Case of Zicherman v. Korean Airlines Co. in 1996, [23] the court held that on the issue of whether damages claim on pure mental injury should be supported through the means of private international law; provided that damages claim on pure mental injury is recognized by the lex causae as guide by the conflicts law in the country of appellate court, the plaintiff may obtain damages from the air carrier. The author expresses reservations about this. According to the Warsaw System which dedicates to unify the liabilities of international air carriers, it is intended for realizing the benefits of adopting uniform measures to regulate transportation conditions including the certificates to be used and the liabilities of carriers etc. [24] If courts in signatory countries have discretions with interpretation and application of the Convention, it would render all intention and efforts in establishing a unified international aviation law into nothing but formality. It is because even without the bias of local law supremacy, the judges would inevitably be subject to the latent impact of his own underlying legal theory and thinking stereotypes, i.e., homeward trend. [25] Meanwhile, with five jurisdictions established under the Montreal Convention in 1999, it is foreseeable that more "forum shopping" phenomena will inevitably take place, which is bound to fuel the chaos of mixed application of private international aviation laws and conventions, thwarting the progress towards unification of private international aviation laws. Hence, in long-term view, to properly resolve the issue of mental injury damages of international air passenger, the hope hinges on clarification of terminology and concepts adopted in clauses of relevant conventions, as well as timely revisions of contents in the conventions, so as to adapt them to the needs of advancing international air transportation sector and human rights theorization.

\section{References}

[1] Ruwantissa I. R. Abeyratne, Aviation Trends in the New Millennium. Ashgate, 2001, p. 247.

[2] He Xiangju, An Investigation of the Issues on Passenger Mental Damages in International Aviation Laws. ECUPL Journal, 2004, the 5th issue. Zhang Jun, Weakness of Air Passengers and Construction of its Balance Mechanism, Academics, 2017, pp. 179-185.

[3] Wang Zejian, Civil Law Theory and Judicial Precedents (VI). China University of Political Science and Law Press, 1998, p. 54. 
[4] Wang Liming, On Breach Liabilities. China University of Political Science and Law Press, 2003, p. 563. Li Hui, The Construction of Compensation for Mental Damage in Breach of Contract in China, Commercial Research, 2015 (8), pp. 181-186.

[5] Charles L Knap \& Crystal, Problems in Contract Law. Little Brown and Company, 1998. p 978. Zhou Hua, To Limit Compensation in the Name of Damage-Analysis on Self Correction of Complete Compensation Principle in Tort Law, Hebei Law Science, 2017 (5), pp. 46-57.

[6] Strictly speaking, the Kuala Lumpur Agreement and the Montreal Agreement are not international conventions, but they serve de facto as material modification to the Warsaw Convention, and are playing their roles in practice and therefore usually considered as part of the Warsaw System.

[7] See http://library.arcticportal.org/1588/1/Warsaw1929.pdf.

[8] Zhao Weitian, International Aviation Laws. Social Sciences Academic Press, 2000, p.327.

[9] John F. Easton, Jennifer E. trock and Kent A. Radford: " $A$ Continuum of Bodily Injury Under The Warsaw Convention", Journal of Air Law and Commerce, Fall, 2003. George N. Tompkins, Are the Objectives of the 1999 Montreal Convention in Danger of Failure?, Air and Space Law, 2014 (3), pp. 203-214.

[10] "Personal injury" is an injury not to property, but to the body, mind, or emotions.

http://www.nolo.com/lawcenter/dictionary/dictionary listing.c fm/Term/DEEE0E11-E3A5-4E2D-9E36FA5CC1F46D61/alph a/P, retrieved on July 11, 2017.

[11] Vijay Poonoosamy, Report on Modernization and Unification of the Warsaw System by Rapporteur, document from the 30th meeting of the Legal Committee of ICAO (LC/30-WP/4 Appendix A). Cited from International Aviation Private Laws by Tang Mingyu \& Chen Yu, Law Press China, 2004, p.256.

[12] Tang Mingyu \& Chen Yu, International Aviation Private Laws, Law Press China, 2004, p.257.

[13] See

http://www.jus.uio.no/lm/air.carriage.unification.convention.m ontreal.1999/17.html.

[14] Ruwantissa I. R. Abeyratne, "Mental Distress in Aviation Claim-Emergent Trends", Journal of Air Law and Commerce, Spring, 2000. Jae Woon Lee, Joseph Charles Wheeler, Air Carrier Liability for Delay: A Plea to Return to International Uniformity, J. Air L. \& Com. 2012, p. 77.

[15] Zhao Wei Tian, International Aviation Law, Social Science Academic Press (China), 2000, p.326. Zhai Yehu, On Laws Applying of the International Aviation Accident Compensation, Law Science Magazine, 2014 (7), pp. 91-96.
[16] 872 F. 2d. 1462 (11th Cir. 1989). The Supreme Court of the United States' final verdict reference number: 499 U.S. 530 (1991)/ Cited from International Aviation Private Laws by Tang Mingyu \& Chen Yu, Law Press China, 2004, p 254.

[17] In Article 110 of General Provisions of Civil Law, "natural persons enjoy the right to life, body rights, the right to health, name rights, image rights, reputation rights, honor rights, privacy rights, the right to marital autonomy and other such rights."

[18] In Clause 4 of Article 10 of Answers to Several Issues Pertaining to Trial of Reputation Right Related Cases by the Supreme People's Court, "where a citizen or legal person claims damages for reputation tort, the tortfeasor shall be liable for the economic losses caused by such tort, which shall be decided by the People's Court of jurisdiction based on the degree of fault on the tortfeasor's part, specific nature of the tort and the consequence of mental injury it causes to the victim."

[19] In Article 1 of the Interpretation of the Supreme People's Court of Some Issues concerning the Application of Law for the Trial of Cases on Compensation for Personal Injury, "where a claimant pursues compensation for property damage or mental injury from an obligor on ground of harm to life, health or body, the People's Court of jurisdiction shall accept such case."

[20] In Article 18 of the Interpretation of the Supreme People's Court of Some Issues concerning the Application of Law for the Trial of Cases on Compensation for Personal Injury, "where a claimant pursues solatium for mental injury as close relative of the victim or the dead who sustained such injury, it shall be determined in accordance with Interpretation of the Supreme People's Court on Problems regarding the Ascertainment of Compensation Liability for Emotional Damages in Civil Torts."

[21] Gao Wanquan, Ding Xiaoyan, International Air Passenger Tort Damages Claim Case Lu Hong v. United Airlines. Gazette of the Supreme People's Court of the People's Republic of China, 2002, Issue 4. He Dawei, The Study on Legal Nature of Public Air Carrier's General Conditions of Carriage and the Resolution of Difficulties in Its Application, Political Science and Law, 2018 (1), pp. 134-149.

[22] Shan Hailing, Liang Min, Analysis of International Air Passenger Tort Damages Claim Case Lu Hong v. United Airlines. The People's Judicature, 2003, Issue 10.

[23] Zicherman v. Korean Air Lines Co., 516 U.S. 217, 226 (1996).

[24] Preface of Warsaw Convention (1929).

[25] Larry A. DiMatteo, Lucien J. Dhooge, Stephaine Greene, Virginia G. Maurer, Marisa Anne Pagnattaro. International Sales Law-A Critical Analysis of CISG Jurisprudence. Cambridge University Press. New York. 2005, p. 23. 